AperTO - Archivio Istituzionale Open Access dell'Università di Torino

\title{
Autologous hematopoietic stem cell transplantation in Systemic Lupus Erythematosus and antiphospholipid syndrome: A systematic review
}

\section{This is the author's manuscript}

Original Citation:

Availability:

This version is available http://hdl.handle.net/2318/1634215

since 2019-02-13T14:54:31Z

Published version:

DOI:10.1016/j.autrev.2017.03.008

Terms of use:

Open Access

Anyone can freely access the full text of works made available as "Open Access". Works made available under a Creative Commons license can be used according to the terms and conditions of said license. Use of all other works requires consent of the right holder (author or publisher) if not exempted from copyright protection by the applicable law. 
This Accepted Author Manuscript (AAM) is copyrighted and published by Elsevier. It is posted here by agreement between Elsevier and the University of Turin. Changes resulting from the publishing process - such as editing, corrections, structural formatting, and other quality control mechanisms - may not be reflected in this version of the text. The definitive version of the text was subsequently published in AUTOIMMUNITY REVIEWS, 16 (5), 2017, 10.1016/j.autrev.2017.03.008.

You may download, copy and otherwise use the AAM for non-commercial purposes provided that your license is limited by the following restrictions:

(1) You may use this AAM for non-commercial purposes only under the terms of the CC-BY-NC-ND license.

(2) The integrity of the work and identification of the author, copyright owner, and publisher must be preserved in any copy.

(3) You must attribute this AAM in the following format: Creative Commons BY-NC-ND license (http://creativecommons.org/licenses/by-nc-nd/4.0/deed.en), 10.1016/j.autrev.2017.03.008

The publisher's version is available at:

http://linkinghub.elsevier.com/retrieve/pii/S1568997217300617

When citing, please refer to the published version.

Link to this full text:

http://hdl.handle.net/2318/1634215 
Autologous Hematopoietic Stem Cell Transplantation in Systemic Lupus Erythematosus and Antiphospholipid Syndrome: a systematic review.

Alessia Leone ${ }^{1}$, Massimo Radin ${ }^{2,3}$, Ahlam Almarzooqi $\mathrm{M}^{4}$, Jamal AlSaleh ${ }^{4}$, Dario Roccatello ${ }^{2,3}$, Savino Sciascia ${ }^{2,3}$, Munther Khamashta ${ }^{4,5}$.

1. Ashford and St Peter's Hospitals NHS Foundation Trust, Surrey, UK

2. Center of Research of Immunopathology and Rare Diseases- Coordinating Center of Piemonte and Valle d'Aosta Network for Rare Diseases, Department of Clinical and Biological Sciences, S. Giovanni Bosco Hospital, Turin, Italy

3. SCDU Nephrology and Dialysis, S. Giovanni Bosco Hospital, Turin, Italy

4. Department of Rheumatology, Dubai Hospital, Dubai, UAE

5. Lupus Research Unit, Guy's and St Thomas' Hospitals NHS Foundation Trust, London, UK; Lupus Research Unit, Division of Women's Health, King's College London, London, UK.

Running title: HSCT in SLE and APS

Keywords: autologous hematopoietic stem cell transplantation, systemic lupus erythematosus, antiphospholipid syndrome, anticardiolipin, lupus anticoagulant, thrombosis

\section{Corresponding author:}

Savino Sciascia, MD, PhD. Center of Research of Immunopathology and Rare Diseases- Coordinating Center of the Network for Rare Diseases of Piedmont and Aosta Valley, Department of Clinical and Biological Sciences, University of Turin, San Giovanni Hospital, piazza del donatore di Sangue 3, 10054, Turin, Italy +390112402056 savino.sciascia@unito.it 


\begin{abstract}
Background

Hematopoietic stem cell transplantation (HSCT) has been proposed as a therapeutic option for patients with Systemic Lupus Erythematosus (SLE) refractory to standard therapy. This therapeutic approach has been applied to other severe autoimmune diseases refractory to standard therapy with promising results.
\end{abstract}

Aim

To systematically review the literature and analyze the available evidence on HSCT therapy in patients with SLE and antiphospholipid syndrome (APS), with a focus on therapy efficacy and occurrence of adverse events.

\title{
Methods
}

A detailed literature search, applied to Ovid MEDLINE, In-Process and Other Non-Indexed Citation and Ovid Medline 1986 to 2014, has been developed a priori to identify articles that reported findings from clinical and laboratory studies that investigated the effect of HCT in patients with SLE.

\section{Results}

25 studies met all inclusion criteria, including a total of 279 SLE patients; of those, 54 patients also fulfilled the classification criteria of APS. The majority of the studies reported an improvement after HSCT in terms of diseases activity control (assessed with SLEDAI, or time-free from diseases) or overall survival. However, one study reported no net benefit of HSCT when compared to immunosuppression alone. One retrospective study reported an overall survival at 5 years of $81 \%$ in 28 SLE patients.

Of note, 5 cases $(9.3 \%)$ of aPL negativization were reported after HSCT in the APS patients. When combining these studies and analyzing these patients with APS, 32 out of 44 (73\%) were able to discontinue anticoagulation after HSCT. Our findings also demonstrate a total of 86 infections in the pool of patients (30.8\%), 3 of which resulted in the death of the patient (1.3\%). We observed an annual incidence of infection of $11.9 \%$ with a mean follow up of 36.2 months.

\section{Conclusion}


Preliminary results of HSCT as a therapeutic option for SLE appear promising. Further studies are warranted in order to assess the safety of the procedure for both the occurrence of secondary autoimmune disease and the rate of infection. However, the rate of adverse effects confines this option to very selected cases of SLE patients resistant or refractory to standard approaches.

\section{Highlights}

- Hematopoietic stem cell transplantation (HSCT) has been proposed with promising results as a therapeutic option for patients with severe autoimmune diseases refractory to standard therapy.

- The rate of adverse effects confines HSCT to very selected cases of patients with Systemic Lupus Erythematosus resistant or refractory to standard approaches. 


\subsection{Introduction}

Systemic lupus erythematosus (SLE) is a chronic autoimmune disease characterized by a relapsing intermitting course with periods of flares, alternating periods of remission and by highly heterogeneous clinical manifestations with a multi-systemic involvement [1]. The management of SLE is based on nonsteroidal anti-inflammatory drugs, glucocorticoids (GC), hydroxychloroquine (HCQ) and immunosuppressive agents, as well as novel biotechnological therapies [2,3]. Although advances in the treatment of SLE have led to a significant improvement in the prognosis, SLE management remains challenging due to the adverse effects associated with conventional therapies and the occurrence of refractory disease.

Hematopoietic stem cell transplantation (HSCT) has been proposed as an alternative therapeutic option for SLE patients refractory to standard therapy. The initial findings of remission of severe autoimmune disease were described in patients undergoing transplantation for a hematologic disease who also had a coincidental autoimmune disease[4-6]. Following these observations, this therapeutic approach has been applied to other severe autoimmune diseases refractory to standard therapy [7-10] and preliminary results of animal model studies have been promising $[11,12]$. Although the mechanism of remission of disease induced by HSCT is likely to be due to intensive immune suppression, it may also play a role in modifying the immune system after transplant and thus leading to a prolonged period of remission.

In this systematic review, we aim to analyze the available evidence on HSCT therapy in patients with SLE and antiphospholipid syndrome (APS), focusing on therapy efficacy and occurrence of adverse events.

\subsection{Patients and Methods}

Search and Study Selection

A detailed literature search has been developed a priori to identify articles that reported findings from clinical and laboratory studies that investigated the effect of HCT in patients with SLE. Key words and subject terms included ("lupus vulgaris"[MeSH Terms] OR ("lupus"[All Fields] AND "vulgaris"[All Fields]) OR "lupus vulgaris"[All Fields] OR "lupus"[All Fields]) AND (("transplantation"[Subheading] OR "transplantation"[All Fields] OR "transplantation"[MeSH Terms]) OR (autologous[All Fields] AND 
("hematopoietic stem cell transplantation"[MeSH Terms] OR ("hematopoietic"[All Fields] AND "stem"[All Fields] AND "cell"[All Fields] AND "transplantation"[All Fields]) OR "hematopoietic stem cell transplantation"[All Fields] OR ("hematopoietic"[All Fields] AND "cell"[All Fields] AND "transplantation"[All Fields]) OR "hematopoietic cell transplantation"[All Fields])) OR allogenic [All Fields]).

The search strategy was applied to Ovid MEDLINE, In-Process and Other Non-Indexed Citation and Ovid Medline 1986 to 2014. References of applicable review articles and included studies were hand searched to identify other relevant studies. No search limits were applied.

All published studies in manuscript form enrolling at least 1 patient with SLE undergoing auto- or allogenic HCT were included. We excluded abstracts not published as full manuscripts. Studies were independently reviewed by 2 authors (AL and AA). Any disagreements were resolved by consensus with other authors (SS, MR, MK).

\subsection{Data Collection}

Data were collected on study details, patient characteristics, clinical outcomes [overall survival (OS)] and harms [transplantation-related morbidity (TRM), disease relapse, autoantibodies seroconversion]. Methodological quality utilizing a standardized data extraction form (Appendix 1). All data were independently extracted by 2 authors ( $A L$ and $A A)$. Extracted data was verified for accuracy by another author (SS.). Methodological quality of included cohort studies was assessed using the Newcastle-Ottawa scale modified for single-arm cohort [13].

\subsection{Data Analysis and Statistical Methods}

A proportion was calculated for each outcome. When possible, effect estimates from studies similar in terms of study design, included patients, interventions, and outcomes were pooled together. All results are reported as a proportion and a 95\% confidence interval $(\mathrm{Cl})$. Heterogeneity was tested using the $\mathrm{I}^{2}$ test. An $\mathrm{I}^{2}$ above $30 \%$ was considered moderate heterogeneity and above $60 \%$ was considered high heterogeneity. 
This systematic review is reported according to the Preferred Reporting Items for Systematic Reviews and Meta-Analyses guidelines [14].

\subsection{Results}

\subsection{Search Results and Characteristics of Included Studies}

The search identified 2088 studies and 25 met all inclusion criteria [15-39]. The study selection process is reported in Figure 1. The use of allogenic/auto-HCT as rescue therapy for SLE/SAPS was assessed using data from 2 prospective [15,36], 10 retrospective studies [16-23, 34]and 13 case reports [24-33,35,37-39], for a total of 279 SLE patients. Of those, 54 patients also fulfilled the criteria of APS. The demographic and pretransplant clinical characteristics of the patients of included studies are reported in Tables 1 and 2 for patients with SLE and for SLE and APS, respectively.

\subsection{Control of disease activity}

3 out of 12 studies (2 prospective and 10 retrospective) assessed SLE activity with SLE Disease Activity Index (SLEDAI) $[15,18,20]$. Traynor and colleagues [15] reported that following HSCT a gradual, but marked, improvement in their cohort ( $<5$ of SLEDAlin 12 patients). Gualandi et al. [18] demonstrated that 5 SLE patients had a decrease from 90 of cumulative SLEDAI index to 9 after transplant. Whereas another study [20] reported an overall decrease of SLEDAI after either immunosuppression alone or followed by transplant, with no statistical difference between the two groups.

4 studies reported the disease-free survival in their cohort of patients $[17,21,23,34]$. Vanikar et al. [17] reported a disease-free interval of 7.35 months; Alchi et al. [23] showed a 5 year disease-free survival of 29\%; Song et al. [21] reported a progression-free survival of $64.7 \%$ (significantly higher than the control group), and finally Burt et al. [34] described a 50\% disease-free survival at 5 years.

\section{4 aPL profile changes after HSCT}


It is worth noting that studies that included SLE patients with APS (SAPS), reported 4 cases $(7.4 \%)$ of aPL negativization after transplant and one study reported one case (1.9\%) of aPL negativization after transplant in the first 6 months of follow-up. Statkute et al. [37] stated that 14 out of 22 SAPS patients were able to discontinue anticoagulation, while Burt et al. [34] described 18 out of 22 SAPS patients that were able to stop anticoagulation therapy after transplant. No APS-related recurrences were described during the follow up (range=8-29 months).

\subsection{Overall-survival and mortality}

One retrospective study out of twelve total studies [23] reported the 5 years overall survival outcome. Alchi et al. [23] reported that in their 28 SLE patients the OS was $81 \%$ (5 patients died in 2 years after treatment, 3 deaths were caused by infections, 1 progressive SLE and 1 caused by autoimmune haemolytic anaemia). Burt et al observed in 50 SLE patients a disease-free survival at 5 years of $50 \%$ ( 2 patients died after mobilization: one active lupus and one and one from mucormycosis).

Song et al [21], reported that in their study of 17 SLE patients there were 2 deaths during the follow up period of 89 months. Paquini et al [22], with a cohort of 27 SLE patients, reported 8 deaths in a follow up period of 31 months and lastly Loh et al. [16] reported 3 deaths (2 SLE progression and the third following an accident). Furthermore, a case report described the death of all three of these patients due to transplant related complications during the follow up of 60 months [30].

Twenty studies did not report deaths during their follow-up period (range= 7-70 months).

When pooling together these studies, we observed an overall mortality of $8.3 \%$ with a mean follow-up of 36.2 months.

The heterogeneity between studies was high $\left(I^{2}=87 \%\right)$.

The results describing outcomes, mortality and post-transplant clinical characteristics of the patients included in the analysis are summarized in Table 3 and 4. 


\subsection{Adverse events (AEs)}

In the 25 studies included, we observed a total of 86 infections (30.8\%), 3 of which resulted in the death of the patient (1.3\%). When pooling together the results from the studies analyzed, there was an annual incidence of infections of $11.9 \%$ with a mean follow up of 36.2 months. Other adverse events included one case of allergic reaction to cyclophosphamide $(0.4 \%)$, one case of fever related to G-CSF $(0.4 \%)$, one Epstein Barr-associated lymphoproliferative disorder, one case of angular chelitis (0.4\%), one case of factor VIII inhibitor hemorrhage $(0.4 \%)$, two cases of secondary autoimmune diseases $(0.7 \%)$ (one case of autoimmune hemolytic anemia that caused the death of the patient and one acquired hemophilia), three cases of bone pain $(1.1 \%)$, three cases of mucositis $(1.1 \%)$, three cases of $(1.1 \%)$ enteropathy and finally three cases of severe hemorrhage (1.1\%).

\subsection{Discussion}

Conventional treatments for SLE are typically directed against the adaptive immune response by limiting T and B cell activation, and/or lowering auto-antibody production. The rationale behind HSCT therapy in SLE is based on an initial phase of intensive immune-suppression to ablate the auto-reactive lymphocytes. The second phase is represented by a repopulation of the immune system by transplant with either autologous or allogeneic hematopoietic CD34+ progenitors cells, rescuing the patient from severe cytopenia and/or hematopoietic failure. It has been hypothesized that HSCT might permanently alter the immune system composition by losing T cell-mediated immune memory[4,9]. Although preliminary results described in the literature are promising, it is not clear whether HSCT alone with no intensive immunosuppression regimen could potentially induce remission in SLE patients. Currently, there is only one prospective phase I study that has investigated the safety and efficacy of immune suppression and HSCT in the treatment of SLE [15]. Although all patients included in the study demonstrated a gradual, but marked improvement (both in terms of clinical and laboratory parameters) it is important to note that phase I studies are not powered to determine efficacy of new experimental therapies. 
Interestingly in the studies analysed, antibody negativization occurred in some of patients both for anti-DNA antibodies and antiphospholipid antibodies (aPL). Conversely, aPL negativization following immunosuppression therapy have been only occasionally described [40]. Besides, it is important to note that out of 44 APS reported cases for whom detailed therapy was provided, more than $70 \%$ were able to discontinue anticoagulation after HSCT [34,36-38].

There are several limitations to the studies analysed: low number of patients of the studies included, potential publication bias with studies reporting only positive outcomes, heterogeneity in clinical presentation, and applied protocols of both immunosuppression and HSCT. It is also important to note a high number of infections and adverse events occurred in patients that underwent the protocol of high dose immune suppression regimen followed by HSCT. In fact, the protocol of intense immunosuppression applied to the treatment is intended to ablate the immune system to the point of marrow suppression, and the related adverse events can't be underestimated.

A further obstacle to this therapy, as described by Daikeler and colleagues [41], is the development of secondary autoimmune diseases that may occur after HSCT. In this retrospective study, after autologous HSCT for primary autoimmune diseases, 29 of 347 patients analysed, developed at least one secondary autoimmune disease in the follow up period, and after allogeneic HSCT, 3 of 16 patients. Even though in our analysis only two cases of secondary autoimmune disease were described, Daikeler et al identified, after multivariate analysis, an initial diagnosis of SLE $(P=0.019$; hazard ratio=3.21; $95 \%$ confidence interval, 1.21 8.48) is significant risk factor for developing a secondary autoimmune disease after HSCT.

\subsection{Conclusion}

Despite the limitations of the studies analysed, the preliminary results of intense immunosuppression and HSCT seem promising. Further studies are warranted in order to assess the safety of the procedure both for occurrence of secondary autoimmune diseases and rate of infection. Prior to considering HRCT as a novel and viable therapeutic option, randomized prospective trials are advised in order to determine the efficacy of HSCT alone and its contribution in inducing remission in SLE and APS patients. 
Acknowledgments: None

Disclosure of Conflicts of Interest: None to declare

Funding: None to declare 


\section{References}

[1] Rahman A, Isenberg DA. Systemic lupus erythematosus. N Engl J Med 2008;358:929-39. doi:10.1056/NEJMra071297.

[2] Chan VS-F, Tsang HH-L, Tam RC-Y, Lu L, Lau C-S. B-cell-targeted therapies in systemic lupus erythematosus. Cell Mol Immunol 2013;10:133-42. doi:10.1038/cmi.2012.64.

[3] Schneider M. Pitfalls in lupus. Autoimmun Rev 2016. doi:10.1016/j.autrev.2016.07.033.

[4] Meloni G, Capria S, Vignetti M, Mandelli F, Modena V. Blast crisis of chronic myelogenous leukemia in long-lasting systemic lupus erythematosus: regression of both diseases after autologous bone marrow transplantation. Blood 1997;89:4659.

[5] Lowenthal RM, Cohen ML, Atkinson K, Biggs JC. Apparent cure of rheumatoid arthritis by bone marrow transplantation. J Rheumatol 1993;20:137-40.

[6] Yin JA, Jowitt SN. Resolution of immune-mediated diseases following allogeneic bone marrow transplantation for leukaemia. Bone Marrow Transplant 1992;9:31-3.

[7] de Buys P, Khanna D, Furst DE. Hemopoietic stem cell transplantation in rheumatic diseases - an update. Autoimmun Rev 2005;4:442-9. doi:10.1016/j.autrev.2005.03.003.

[8] Burt RK, Burns W, Hess A. Bone marrow transplantation for multiple sclerosis. Bone Marrow Transplant 1995;16:1-6.

[9] Krance R, Brenner M. BMT beats autoimmune disease. Nat Med 1998;4:153-5.

[10] Alaez C, Loyola M, Murguía A, Flores H, Rodríguez A, Ovilla R, et al. Hematopoietic stem cell transplantation (HSCT): An approach to autoimmunity. Autoimmun Rev 2006;5:167-79. doi:10.1016/j.autrev.2005.06.003.

[11] Wang Y, Hu Q, Madri JA, Rollins SA, Chodera A, Matis LA. Amelioration of lupus-like autoimmune disease in NZB/WF1 mice after treatment with a blocking monoclonal antibody specific for complement component C5. Proc Natl Acad Sci U S A 1996;93:8563-8.

[12] Karussis DM, Vourka-Karussis U, Lehmann D, Abramsky O, Ben-Nun A, Slavin S. Immunomodulation of autoimmunity in MRL/Ipr mice with syngeneic bone marrow transplantation (SBMT). Clin Exp 
Immunol 1995;100:111-7.

[13] Wells GA, Shea B, O'Connell D, Peterson J, Welch V, Losos M TP. The Newcastle-Ottawa Scale (NOS) for assessing the quality of nonrandomised studies in meta-analyses n.d.

[14] http://prisma-statement.org/documents/PRISMA\%202009\%20checklist.pdf n.d.

[15] Traynor AE, Schroeder J, Rosa RM, Cheng D, Stefka J, Mujais S, et al. Treatment of severe systemic lupus erythematosus with high-dose chemotherapy and haemopoietic stem-cell transplantation: a phase I study. Lancet 2000;356:701-7. doi:10.1016/S0140-6736(00)02627-1.

[16] Loh Y, Oyama Y, Statkute L, Traynor A, Satkus J, Quigley K, et al. Autologous hematopoietic stem cell transplantation in systemic lupus erythematosus patients with cardiac dysfunction : feasibility and reversibility of ventricular and valvular dysfunction with transplant-induced remission. Bone Marrow Transpl 2007;40(1):47-53. doi:10.1038/sj.bmt.1705698.

[17] Vanikar A V, Modi PR, Patel RD, Kanodia K V, Shah VR, Trivedi VB, et al. Hematopoietic stem cell transplantation in autoimmune diseases: the Ahmedabad experience. Transplant Proc 2007;39:7038. doi:10.1016/j.transproceed.2007.01.070.

[18] Gualandi F, Bruno B, Van Lint MT, Luchetti S, Uccelli A, Cappello E, et al. Autologous Stem Cell Transplantation for Severe Autoimmune Diseases: A 10-Year Experience. Ann N Y Acad Sci 2007;1110:455-64. doi:10.1196/annals.1423.048.

[19] Carrion F, Nova E, Ruiz C, Diaz F, Inostroza C, Rojo D, et al. Autologous mesenchymal stem cell treatment increased T regulatory cells with no effect on disease activity in two systemic lupus erythematosus patients. Lupus 2010;19:317-22. doi:10.1177/0961203309348983.

[20] Meng J, Wang J, Liang W, Qin S, Wu C. Long-term remission after successful pregnancy in autologous peripheral blood stem cell transplanted system lupus erythematosus patients. Rheumatol Int 2011;31:691-4. doi:10.1007/s00296-010-1588-x.

[21] Song X-N, Lv H-Y, Sun L-X, Meng J-B, Wang J-K, Zhang J-Q, et al. Autologous stem cell transplantation for systemic lupus erythematosus: report of efficacy and safety at 7 years of follow-up in 17 patients. Transplant Proc 2011;43:1924-7. doi:10.1016/j.transproceed.2011.03.039. 
[22] Pasquini MC, Voltarelli J, Atkins HL, Hamerschlak N, Zhong X, Ahn KW, et al. Transplantation for Autoimmune Diseases in North and South America: A Report of the Center for International Blood and Marrow Transplant Research. Biol Blood Marrow Transplant 2012;18:1471-8. doi:10.1016/j.bbmt.2012.06.003.

[23] Alchi B, Jayne D, Labopin M, Kotova O, Sergeevicheva V, Alexander T, et al. Autologous haematopoietic stem cell transplantation for systemic lupus erythematosus: data from the European Group for Blood and Marrow Transplantation registry. Lupus 2012;22(3):1-9. doi:10.1177/0961203312470729.

[24] Euler HH, Marmont AM, Bacigalupo A, Fastenrath S, Dreger P, Hoffknecht M, et al. Early recurrence or persistence of autoimmune diseases after unmanipulated autologous stem cell transplantation. Blood 1996;88:3621-5.

[25] Snowden JA, Patton WN, O'Donnell JL, Hannah EE, Hart DN. Prolonged remission of longstanding systemic lupus erythematosus after autologous bone marrow transplant for non-Hodgkin's lymphoma. Bone Marrow Transplant 1997;19:1247-50. doi:10.1038/sj.bmt.1700815.

[26] Marmont AM, van Lint MT, Gualandi F, Bacigalupo A. Autologous marrow stem cell transplantation for severe systemic lupus erythematosus of long duration. Lupus 1997;6:545-8.

[27] Burt RK, Traynor AE, Pope R, Schroeder J, Cohen B, Karlin KH, et al. Treatment of autoimmune disease by intense immunosuppressive conditioning and autologous hematopoietic stem cell transplantation. Blood 1998;92:3505-14.

[28] Fouillard L, Gorin NC, Laporte JP, Leon A, Brantus JF, Miossec P. Control of severe systemic lupus erythematosus after high-dose immunusuppressive therapy and transplantation of CD34+ purified autologous stem cells from peripheral blood. Lupus 1999;8:320-3.

[29] Brunner M, Greinix HT, Redlich K, Knöbl P, Smolen J, Leitner G, et al. Autologous blood stem cell transplantation in refractory systemic lupus erythematosus with severe pulmonary impairment: A case report. Arthritis Rheum 2002;46:1580-4. doi:10.1002/art.10282.

[30] Lisukov IA, Sizikova SA, Kulagin AD, Kruchkova I V, Gilevich A V, Konenkova LP, et al. High-dose 
immunosuppression with autologous stem cell transplantation in severe refractory systemic lupus erythematosus. Lupus 2004;13:89-94.

[31] Talaulikar D, Tymms KE, Prosser I, Smith R. Autologous peripheral blood stem cell transplantation with in vivo T-cell depletion for life threatening refractory systemic lupus erythematosus. Lupus 2005;14:159-63.

[32] Marmont AM, Gualandi F, van Lint MT, Guastoni C, Bacigalupo A. Long term complete remission of severe nephrotic syndrome secondary to diffuse global (IV-G) lupus nephritis following autologous, haematopoietic peripheral stem (CD34+) cell transplantation. Lupus 2006;15:44-6.

[33] Alexander T, Schneider S, Hoyer B, Cheng Q, Thiel A, Ziemer S, et al. Development and resolution of secondary autoimmunity after autologous haematopoietic stem cell transplantation for systemic lupus erythematosus: competition of plasma cells for survival niches? Ann Rheum Dis 2013;72:1102-4. doi:10.1136/annrheumdis-2012-202729.

[34] Burt RK, Traynor A, Statkute L, Barr WG, Rosa R, Schroeder J, et al. Nonmyeloablative Hematopoietic Stem Cell Transplantation for Systemic Lupus Erythematosus. JAMA 2006;295:527-35. doi:10.1001/jama.295.5.527.

[35] Hashimoto N, Iwasaki T, Sekiguchi M, Takatsuka H, Okamoto T, Hashimoto T, et al. Autologous hematopoietic stem cell transplantation for refractory antiphospholipid syndrome causing myocardial necrosis. Bone Marrow Transpl 2004;33:863-6. doi:10.1038/sj.bmt.1704432.

[36] Rosen O, Thiel a, Massenkeil G, Hiepe F, Häupl T, Radtke H, et al. Autologous stem-cell transplantation in refractory autoimmune diseases after in vivo immunoablation and ex vivo depletion of mononuclear cells. Arthritis Res 2000;2:327-36. doi:10.1186/ar107.

[37] Statkute L, Traynor A, Oyama Y, Yaung K, Verda L, Krosnjar N, et al. Antiphospholipid syndrome in patients with systemic lupus erythematosus treated by autologous hematopoietic stem cell transplantation. Blood 2005;106:2700-9. doi:10.1182/blood-2005-01-0330.

[38] Trysberg E, Lindgren I, Tarkowski A. Autologous stem cell transplantation in a case of treatment resistant central nervous system lupus. Ann Rheum Dis 2000;59:236-8. doi:10.1136/ard.59.3.236. 
[39] Musso M, Porretto F, Crescimanno A, Bondì F, Polizzi V, Scalone R, et al. Successful treatment of resistant thrombotic thrombocytopenic purpura/hemolytic uremic syndrome with autologous peripheral blood stem and progenitor (CD34+) cell transplantation. Bone Marrow Transplant 1999;24:207-9. doi:10.1038/sj.bmt.1701859.

[40] Sciascia S, Naretto C, Rossi D, Bazzan M, Roccatello D. Treatment-induced downregulation of antiphospholipid antibodies: Effect of rituximab alone on clinical and laboratory features of antiphospholipid syndrome. Lupus 2011;20. doi:10.1177/0961203311400115.

[41] Daikeler T, Tyndall A. Autoimmunity following haematopoietic stem-cell transplantation. Best Pract Res Clin Haematol 2007;20:349-60. doi:10.1016/j.beha.2006.09.008. 


\begin{tabular}{|c|c|c|c|c|c|c|c|c|c|c|}
\hline $\begin{array}{l}\text { First } \\
\text { Author }\end{array}$ & Year & $\begin{array}{l}\text { Study } \\
\text { design }\end{array}$ & $\begin{array}{l}\text { Number of } \\
\text { Patients }\end{array}$ & $\begin{array}{l}\text { Controls } \\
\text { (if any) }\end{array}$ & Female (n.) & age (mean) & $\begin{array}{c}\text { transplant } \\
\text { details (type) }\end{array}$ & $\begin{array}{c}\text { Indication for } \\
\text { transplant }\end{array}$ & $\begin{array}{c}\text { Treatment for } \\
\text { ablation }\end{array}$ & $\begin{array}{c}\text { Treatment for after } \\
\text { transplant }\end{array}$ \\
\hline \multicolumn{11}{|c|}{ Phase 1 trial } \\
\hline $\begin{array}{l}\text { Traynor } \\
\text { et al. } \\
\text { [15] }\end{array}$ & 2000 & $\begin{array}{l}\text { Phase } \\
1 \\
\text { study }\end{array}$ & 7 & 0 & $\mathrm{NR}$ & 27 & $\begin{array}{c}\text { Autologous } \\
\text { HSCT }\end{array}$ & refractory SLE & $\begin{array}{c}\text { CYC (200mg/kg), } \\
\text { MTP (1g), and ATG } \\
(90 \mathrm{mg} / \mathrm{kg})\end{array}$ & $\begin{array}{c}3 \text { patients were } \\
\text { tapered to } 5 \mathrm{mg} \text { PDN } \\
\text { daily and the other } 4 \\
\text { patients had their } \\
\text { medication } \\
\text { discontinued. }\end{array}$ \\
\hline \multicolumn{11}{|c|}{ Retrospective studies } \\
\hline $\begin{array}{l}\text { Loh et al. } \\
{[16]}\end{array}$ & 2007 & RS & $\begin{array}{c}55 \text { (13 pts } \\
\text { with } \\
\text { significant } \\
\text { cardiac } \\
\text { abnormalities) }\end{array}$ & 0 & $\begin{array}{l}12 \text { of the } 13 \\
\text { with cardiac } \\
\text { abnormalities }\end{array}$ & $\begin{array}{l}39.3 \text { (median } \\
\text { age of the } 13 \\
\text { with cardiac } \\
\text { abnormalities) }\end{array}$ & $\begin{array}{c}\text { Autologous } \\
\text { HSCT }\end{array}$ & $\begin{array}{c}\text { of the 13: } \\
\text { nephritis } \\
(n=7), \\
\text { cerebritis } \\
(n=8), \\
\text { refractory } \\
\text { cytopenia } \\
(n=4), \text { APS } \\
(n=8), \\
\text { pulmonary } \\
\text { involvement } \\
(n=7), \text { serositis } \\
(n=4) \text { and } \\
\text { cardiac } \\
\text { dysfunction } \\
(n=2)\end{array}$ & $\begin{array}{c}\text { IV CYC }+ \\
\text { ATG/alemtuzumab }\end{array}$ & NR \\
\hline $\begin{array}{l}\text { Vanikar } \\
\text { et al. [17] }\end{array}$ & 2007 & RS & 27 & 0 & 24 & 24,2 & $\begin{array}{l}\text { Allogeneic } \\
\text { HSCT }\end{array}$ & NR & CYC, PDN, ATG & NR \\
\hline $\begin{array}{l}\text { Gualandi } \\
\text { et al. [18] }\end{array}$ & 2007 & RS & 5 & 0 & NR & NR & $\begin{array}{l}\text { Autologous } \\
\text { BMT/HSCT }\end{array}$ & NR & BEAM + ATG & $\begin{array}{l}\text { No patient is taking } \\
\text { over } 5 \mathrm{mg} \text { of } \\
\text { prednisone following } \\
\text { transplant' }\end{array}$ \\
\hline $\begin{array}{l}\text { Carrion et } \\
\text { al. [19] }\end{array}$ & 2010 & RS & 2 & 0 & 2 & 22 & $\begin{array}{c}\text { auto- } \\
\text { mesenchymal } \\
\text { stem cell } \\
\text { transplant }\end{array}$ & severe SLE & NR & NR \\
\hline $\begin{array}{l}\text { Meng et } \\
\text { al. } \\
{[20]}\end{array}$ & 2011 & RS & 11 & $39^{\wedge}$ & $\begin{array}{l}\text { (all - as paper } \\
\text { focuses on } \\
\text { pregnancy } \\
\text { outcomes) }\end{array}$ & 29 & $\begin{array}{l}\text { Autologous } \\
\text { HSCT }\end{array}$ & refractory SLE & CYC/ATG regimen & NR \\
\hline $\begin{array}{l}\text { Song et } \\
\text { al. } \\
{[21]}\end{array}$ & 2011 & RS & 17 & 20 & 14 & 23 & $\begin{array}{c}\text { Autologous } \\
\text { HSCT }\end{array}$ & severe SLE* & CYC/ATG regimen & $\begin{array}{c}\text { Glucocorticoids } \\
\text { discontinued at } 6(12) \\
\text { or } 12 \text { months (4) } \\
\text { except one patient } \\
\text { who continuously } \\
\text { takes prednisone } \\
5 \mathrm{mg} / \text { day. }\end{array}$ \\
\hline $\begin{array}{l}\text { Pasquini } \\
\text { et al. [22] }\end{array}$ & 2012 & RS & 27 & 0 & NR & NR & $\begin{array}{c}\text { Autologous } \\
\text { or Allogeneic } \\
\text { HSCT }\end{array}$ & NR & CYC/ATG regimen & NR \\
\hline $\begin{array}{l}\text { Alchi et } \\
\text { al. } \\
\text { [23] }\end{array}$ & 2013 & RS & 28 & 0 & 25 & 29 & $\begin{array}{c}\text { Autologous } \\
\text { HSCT }\end{array}$ & refractory SLE & $\begin{array}{c}\text { low or } \\
\text { intermediate } \\
\text { intensity CYC/ATG } \\
\text { regimen }\end{array}$ & $\begin{array}{c}12 \text { patients had an } \\
\text { immunosuppressive } \\
\text { drug (Cy or MMF) or } \\
\text { biological agent } \\
\text { introduced after } \\
\text { HSCT.. PDN was } \\
\text { withdrawn in } 4 / 26 \\
\text { and the } 22 / 26 \\
\text { remaining patients } \\
\text { were receiving PDN } \\
\text { in doses of 3-100 mg } \\
\text { daily at time of last } \\
\text { follow-up. }\end{array}$ \\
\hline
\end{tabular}




\begin{tabular}{|c|c|c|c|c|c|c|c|c|c|c|}
\hline $\begin{array}{l}\text { Euler et } \\
\text { al. } \\
{[24]}\end{array}$ & 1996 & $\mathrm{CR}$ & 1 & 0 & 1 & 28 & $\begin{array}{c}\text { Autologous } \\
\text { HSCT }\end{array}$ & $\begin{array}{l}\text { Severe SLE and } \\
\text { non-Hodgkin } \\
\text { lymphoma }\end{array}$ & BEAM regimen & NR \\
\hline $\begin{array}{l}\text { Snowden } \\
\text { et al. } \\
{[25]}\end{array}$ & 1997 & $\mathrm{CR}$ & 1 & 0 & 1 & NR & $\begin{array}{c}\text { Autologous } \\
\text { HSCT }\end{array}$ & $\begin{array}{l}\text { non-Hodgkin } \\
\text { lymphoma }\end{array}$ & CBV regimen & $\begin{array}{c}\text { PDN was reduced } \\
1 \mathrm{mg} \text { every } 3 \text { weeks } \\
\text { and then } \\
\text { discontinued. Three } \\
\text { years later steroid } \\
\text { treatment was re- } \\
\text { started for } \\
\text { thrombocytopenia }\end{array}$ \\
\hline $\begin{array}{l}\text { Marmont } \\
\text { et al. } \\
{[26]}\end{array}$ & 1997 & $\mathrm{CR}$ & 1 & 0 & 1 & 46 & $\begin{array}{c}\text { Autologous } \\
\text { HSCT }\end{array}$ & $\begin{array}{c}\text { severe } \\
\text { refractory SLE }\end{array}$ & $\begin{array}{c}\text { 15mg/kg Thiotepa } \\
\text { / 100mg CYC }\end{array}$ & $\begin{array}{l}\text { seven months after } \\
\text { transplant } \\
\text { corticosteroid } \\
\text { requirement is } \\
10 \mathrm{mg} / \text { daily }\end{array}$ \\
\hline $\begin{array}{l}\text { Burt et al. } \\
{[27]}\end{array}$ & 1998 & $\mathrm{CR}$ & 2 & 0 & NR & NR & $\begin{array}{c}\text { Autologous } \\
\text { HSCT }\end{array}$ & $\begin{array}{l}\text { acute renal } \\
\text { failure and } \\
\text { recurrent } \\
\text { alveolar } \\
\text { hemorrhage }\end{array}$ & $\begin{array}{c}\text { Cymethyl- } \\
\text { prednisolone/ATG } \\
\text { regimen }\end{array}$ & $\begin{array}{l}\text { One patient - no } \\
\text { treatment, other } \\
\text { patient - tapering of } \\
\text { steroids }\end{array}$ \\
\hline $\begin{array}{l}\text { Fouillard } \\
\text { et al. [28] }\end{array}$ & 1999 & $\mathrm{CR}$ & 1 & 0 & 1 & 35 & $\begin{array}{c}\text { Autologous } \\
\text { HSCT }\end{array}$ & $\begin{array}{c}\text { severe and } \\
\text { progressive } \\
\text { SLE }\end{array}$ & BEAM regimen & $\begin{array}{l}\text { PDN reduced from } \\
50 \mathrm{mg} \text { to } 12.5 \mathrm{mg}\end{array}$ \\
\hline $\begin{array}{l}\text { Brunner } \\
\text { et al. [29] }\end{array}$ & 2002 & $\mathrm{CR}$ & 1 & 0 & 1 & 18 & $\begin{array}{c}\text { Autologous } \\
\text { HSCT }\end{array}$ & $\begin{array}{l}\text { refractory SLE } \\
\text { with } \\
\text { pulmonary } \\
\text { impairment }\end{array}$ & CYC/ATG regimen & NR \\
\hline $\begin{array}{l}\text { Lisukov et } \\
\text { al. } \\
{[30]}\end{array}$ & 2004 & $\mathrm{CR}$ & 6 & 0 & 6 & 22 & $\begin{array}{c}\text { Autologous } \\
\text { HSCT }\end{array}$ & $\begin{array}{c}\text { severe } \\
\text { refractory SLE }\end{array}$ & $\begin{array}{c}\text { BEAM + ATG } \\
(n=2), \text { melphalan }+ \\
\text { etoposid }(n=2) \\
\text { and CYC/ATG } \\
(n=2)\end{array}$ & $\begin{array}{c}\text { Patient } 1 \text { - oral PDN } \\
\text { withdrawn after } 10 \\
\text { months of BMT, } \\
\text { patient } 2 \text { - } \\
\text { maintenance therapy } \\
\text { of Cy } 100 \mathrm{mg} / \text { day, low } \\
\text { dose corticosteroids } \\
\text { (10-7.5mg/day) and } \\
\text { AZA } 50 \mathrm{mg} / \text { day, } \\
\text { patient } 3 \text { - none } \\
\text { mentioned) }\end{array}$ \\
\hline $\begin{array}{l}\text { Talaulikar } \\
\text { et al. [31] }\end{array}$ & 2005 & $\mathrm{CR}$ & 1 & 0 & 1 & 39 & $\begin{array}{c}\text { Autologous } \\
\text { HSCT }\end{array}$ & refractory SLE & CYC/ATG regimen & PDN 5mg daily \\
\hline $\begin{array}{l}\text { Marmont } \\
\text { et al. } \\
{[32]}\end{array}$ & 2006 & $\mathrm{CR}$ & 1 & 0 & 0 & 26 & $\begin{array}{c}\text { Autologous } \\
\text { HSCT }\end{array}$ & $\begin{array}{c}\text { Diffuse global } \\
\text { lupus nephritis } \\
\text { and refractory } \\
\text { nephrotic } \\
\text { syndrome with } \\
\text { high } \\
\text { proteinuria }\end{array}$ & $\begin{array}{c}\text { Thiotepa } 10 \mathrm{mg} / \mathrm{kg} \\
\text { followed by } \\
\text { cYC100mg/kg }\end{array}$ & $\begin{array}{c}\text { 5mg of PDN every } \\
\text { other day }\end{array}$ \\
\hline $\begin{array}{l}\text { Alexander } \\
\text { et al. [33] }\end{array}$ & 2013 & CR & 1 & 0 & 0 & 21 & $\begin{array}{l}\text { Autologous } \\
\text { HSCT }\end{array}$ & $\begin{array}{c}\text { severe } \\
\text { refractory SLE }\end{array}$ & CYC/ATG regimen & $\begin{array}{l}\text { immunosuppressive } \\
\text { drugs withdrawn }\end{array}$ \\
\hline
\end{tabular}

Table 1. Demographic and pre-transplant clinical characteristics of SLE patients

$N R$, not reported; $R S$, retrospective study; $C R$, case report; ${ }^{\prime} S L E$ patients receiving immunosuppression therapy not transplant; CYC, Cyclophosphamide; MTP, methylprednisolone; PDN, prednisolone; HSCT, Hematopoietic stem cell transplantation; BMT, bone marrow transplantation; *SLE patients with transfusion-dependent cytopenias, severe percarditis, lung/CNS involvement or txresistant glomeruloneprhtitis; ATG, Anti-thymocyte globulin; BEAM, BiCNU-carmustine, Etoposide, Ara-C - cytarabine, Melphalan; CBV, cyclophosphamide, BCNU (carmustine), and VP-16 (etoposide); Cy, cyclosporine; MMF, mycophenolate; AZA, azathioprine; 


\begin{tabular}{|c|c|c|c|c|c|c|c|c|}
\hline $\begin{array}{l}\text { First } \\
\text { Author }\end{array}$ & $\begin{array}{l}\text { Stu } \\
\text { dy } \\
\text { des } \\
\text { ign }\end{array}$ & $\begin{array}{c}\mathbf{N} \\
\# \\
\mathbf{P t} \\
\mathbf{S}\end{array}$ & $\mathbf{F}$ & $\begin{array}{c}\text { age } \\
\text { (mea } \\
\text { n) }\end{array}$ & SAPS & $\begin{array}{l}\text { Indication for transplant (all receiving } \\
\text { Autologous HSCT with CYC/ATG } \\
\text { regimen for ablation) }\end{array}$ & Treatment for after transplant & $\begin{array}{c}\text { anticoagulation } \\
\text { before } \\
\text { transplant } \\
(\mathrm{Y} / \mathrm{N})\end{array}$ \\
\hline $\begin{array}{l}\text { Burt } \\
(2006) \\
{[34]}\end{array}$ & $\mathrm{RC}$ & 50 & $\begin{array}{l}4 \\
3\end{array}$ & 30 & 22 & $\begin{array}{l}\text { refractory SLE and either organ- or } \\
\text { life-threatening visceral involvement }\end{array}$ & NR & $\mathrm{Y}$ \\
\hline $\begin{array}{l}\text { Hashimo } \\
\text { to (2004) } \\
{[35]}\end{array}$ & $\mathrm{CR}$ & 1 & 1 & 27 & 1 & $\begin{array}{l}\text { progressive myocardial damage } \\
\text { caused by APS despite treatment }\end{array}$ & low-dose corticosteroids & $\mathrm{N}$ \\
\hline $\begin{array}{l}\text { Rosen } \\
(2000) \\
{[36]}\end{array}$ & $\begin{array}{l}\text { Pha } \\
\text { se } \\
1 / 2 \\
\text { stu } \\
\text { dy }\end{array}$ & 3 & 2 & 37 & 1 & refractory SLE & $\begin{array}{l}\text { reduced steroid therapy (APS } \\
\text { patient still on warfarin) }\end{array}$ & $\mathrm{Y}$ \\
\hline $\begin{array}{l}\text { Statkute } \\
\text { / Burt } \\
\text { (2005) } \\
\text { [37] }\end{array}$ & $\mathrm{RC}$ & 28 & $\begin{array}{l}2 \\
5\end{array}$ & 29 & 28 & $\begin{array}{l}\text { glomerulonephritis, involvement of } \\
\text { the lung or CNS, transfusion- } \\
\text { dependent autoimmune cytopenias, } \\
\text { or APS }\end{array}$ & $\begin{array}{l}8 / 22 \text { remained on anti-coagulation, } \\
11 / 28 \text { on immunosuppression and } \\
8 / 11 \text { discontinued this within } 13 \\
\text { months }\end{array}$ & $\mathrm{Y}$ \\
\hline $\begin{array}{l}\text { Trysberg } \\
(2000) \\
{[38]}\end{array}$ & $\mathrm{CR}$ & 1 & 1 & 16 & 1 & CNS lupus & $\begin{array}{l}\text { Cyclosporin A, low dose } \\
\text { corticosteroids, azathioprine }\end{array}$ & $\mathrm{Y}$ \\
\hline $\begin{array}{l}\text { Musso } \\
(1999) \\
{[39]}\end{array}$ & $\mathrm{CR}$ & 1 & 1 & 19 & 1 & $\begin{array}{l}\text { SLE complicated by Evans' syndrome, } \\
\text { severe hypercorticism and } \\
\text { amenorrhoea }\end{array}$ & NR & NR \\
\hline
\end{tabular}

Table 2. Demographic and pre-transplant clinical characteristics of SAPS patients

*8 with probable APS, 16 patients were positive for LAC, 20 for anticardiolin antibodies; **3 patients were positive for anticardiolin antibodies 


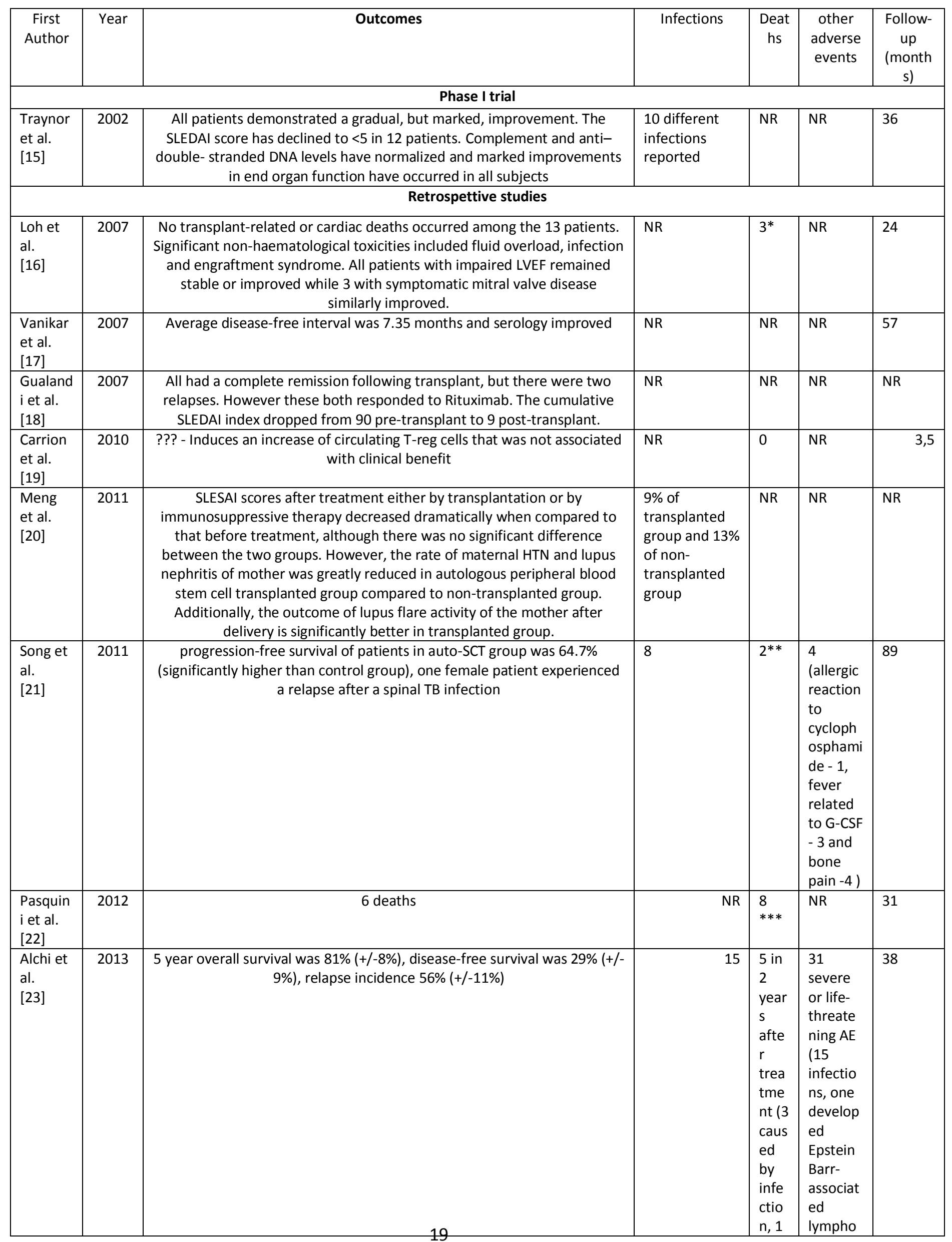




\begin{tabular}{|c|c|c|c|c|c|c|}
\hline & & & & $\begin{array}{l}\text { prog } \\
\text { ressi } \\
\text { ve } \\
\text { SLE, } \\
1 \\
\text { seco } \\
\text { ndar } \\
\text { y } \\
\text { auto } \\
\text { imm } \\
\text { une } \\
\text { dise } \\
\text { ase) }\end{array}$ & $\begin{array}{l}\text { prolifera } \\
\text { tive } \\
\text { disorder } \\
\text {, } 2 \\
\text { develop } \\
\text { ed } \\
\text { seconda } \\
\text { ry } \\
\text { autoim } \\
\text { mune } \\
\text { disease, } \\
\text { one } \\
\text { autoim } \\
\text { mune } \\
\text { haemoly } \\
\text { tic } \\
\text { anaemia } \\
\text {, } \\
\text { acquire } \\
d \\
\text { haemop } \\
\text { hilia, } 2 \\
\text { CV } \\
\text { events) }\end{array}$ & \\
\hline \multicolumn{7}{|c|}{ Case report } \\
\hline $\begin{array}{l}\text { Eular et } \\
\text { al. } \\
{[24]}\end{array}$ & 1996 & $\begin{array}{c}\text { Complete remission of NHL and SLE but serological SLE symptoms } \\
\text { persisted. On day } 352 \text { after transplant, patient showed signs of relapsing } \\
\text { SLE, eventually developing severe thrombocytopenia which eventually led } \\
\text { to a fatal intracerebral hemorrhage on day } 378\end{array}$ & NR & 1 & NR & 12 \\
\hline $\begin{array}{l}\text { Snowde } \\
\text { n et al. } \\
{[25]}\end{array}$ & 1997 & $\begin{array}{c}\text { Patient went into clinical and serological remission following transplant, } \\
\text { however } 3 \text { years later the patient presented with thrombocytopenia (ITP), } \\
\text { which had not previously been a feature of the SKE, necessitating } \\
\text { reintroduction of steroid immunosuppression. }\end{array}$ & $\begin{array}{r}2 \text { (oral herpes } \\
\text { simplex, } \\
\text { pneumocystis } \\
\text { jirovecii } 5 \\
\text { months after } \\
\text { transplant) }\end{array}$ & 0 & $\begin{array}{l}\text { angular } \\
\text { chelitis }\end{array}$ & 36 \\
\hline $\begin{array}{l}\text { Marmo } \\
\text { nt et al. } \\
{[26]}\end{array}$ & 1997 & $\begin{array}{l}\text { Patient obtained good partial remission, reduction in steroid requirement, } \\
\text { and a persistent negativisation of ANA }\end{array}$ & 0 & 0 & 0 & 7 \\
\hline $\begin{array}{l}\text { Burt et } \\
\text { al. } \\
{[27]}\end{array}$ & 1998 & $\begin{array}{l}\text { first patient is off all immunosuppressants for the first time in } 13 \text { years, } \\
\text { second patient - hemoptysis and pulmonary infiltrates have resolved and } \\
\text { steroids are gradually being tapered off. }\end{array}$ & 0 & 0 & 0 & 11 \\
\hline $\begin{array}{l}\text { Fouillar } \\
\text { d et al. } \\
{[28]}\end{array}$ & 1999 & $\begin{array}{c}\text { One year later, the patient is in clinical remission. ANA and anti-SSA } \\
\text { antibodies were undetectable at } 1 \text { and } 6 \text { months after intensification, but } \\
\text { reappeared at low levels at } 9 \text { months. }\end{array}$ & $\begin{array}{l}\text { None during tx } \\
\text { but once } \\
\text { discharged the } \\
\text { patient } \\
\text { developed } \\
\text { herpes simplex } \\
\text { virus on day } 90\end{array}$ & 0 & $\begin{array}{l}\text { grade II } \\
\text { mucositi } \\
\mathrm{s}\end{array}$ & 12 \\
\hline $\begin{array}{l}\text { Brunner } \\
\text { et al. } \\
\text { [29] }\end{array}$ & 2002 & $\begin{array}{l}21 \text { months after the patient was still in clinical remission, with no signs of } \\
\text { SLE-related disease activity and without any immunosuppressive } \\
\text { medications. Her pulmonary function has also returned to normal. }\end{array}$ & $\begin{array}{l}\text { Pseudomonas } \\
\text { aeruginosa }\end{array}$ & 0 & 0 & 21 \\
\hline $\begin{array}{l}\text { Lisukov } \\
\text { et al. } \\
\text { [30] }\end{array}$ & 2004 & $\begin{array}{l}3 \text { patients died on days } 11,22 \text { and } 63 \text { due to transplant related } \\
\text { complications, complete remission of SLE in } 2 \text { patients after } 6 \text { months, } \\
\text { other patient (with CNS lupus) had neurological improvement but } \\
\text { serological SLE symptoms persist (elevated ANA, anti-dsDNA and } \\
\text { anticardiolipin antibodies) and SLEDAI } 2 \text { - partial improvement }\end{array}$ & $\begin{array}{l}4 \text { (pneumonia } \\
\mathrm{x} 2, \mathrm{CMV} \mathrm{x} 1 \text {, } \\
\text { genital herpes } \\
\mathrm{x} 1 \text { ) }\end{array}$ & 3 & $\begin{array}{l}\text { mucositi } \\
\text { s x3, } \\
\text { enterop } \\
\text { athy x } 3 \text {, } \\
\text { severe } \\
\text { haemorr } \\
\text { hage } x 2 \text {, } \\
\text { sepsis } \\
\text { x3 }\end{array}$ & $\begin{array}{l}60 \text { and } \\
6 \\
\text { months } \\
\text { for } 2 \\
\text { patients } \\
- \\
\text { complet } \\
\text { e } \\
\text { remissi }\end{array}$ \\
\hline
\end{tabular}




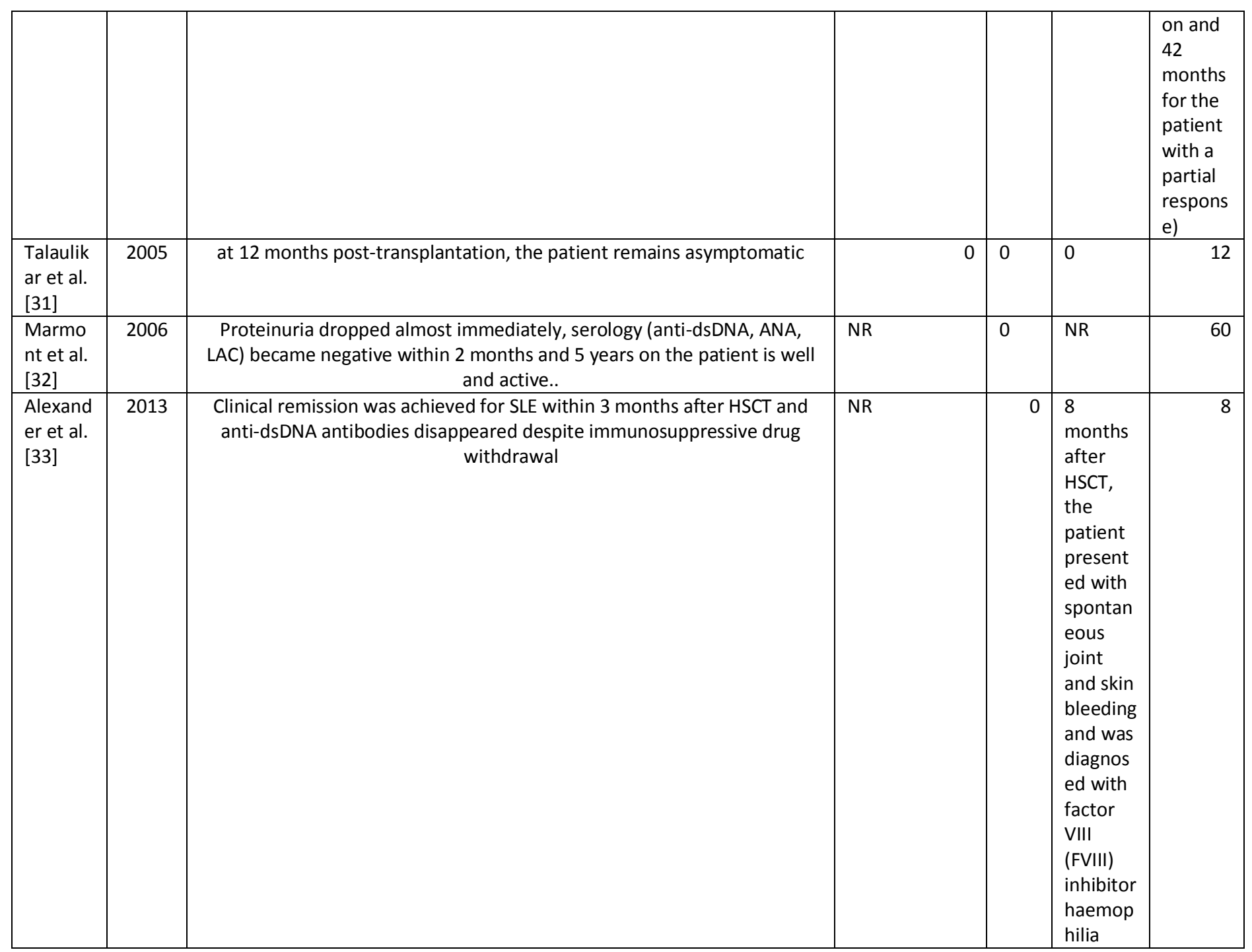

Table 3. Outcomes, mortality and post-transplant clinical characteristics of SLE patients

* Three patients died; two from SLE progression/relapse at 11.5 months and 19 months post-transplant, respectively and the third folllwing an accident at 8 months; ${ }^{* *}$ severe pneumonia - 33 months after and heart failure - 64 months after; ${ }^{* * *} 6$ from infestations, 1 from active SLE and 1 from graft failure. 


\begin{tabular}{|c|c|c|c|c|c|c|}
\hline First Author & Outcomes & Infections & Deaths & $\begin{array}{l}\text { Follo } \\
\text { w-up } \\
\text { (mon } \\
\text { ths) }\end{array}$ & $\begin{array}{l}\text { aPL } \\
\text { negativizati } \\
\text { on after } \\
\text { transplant }\end{array}$ & $\begin{array}{l}\text { Patient } \\
\text { anticoagulated } \\
\text { after trasplant }\end{array}$ \\
\hline $\begin{array}{l}\text { Burt } \\
(2006) \\
{[34]}\end{array}$ & $\begin{array}{l}50 \% \text { survived disease-free at } 5 \text { years, } 84 \% \\
\text { survived at } 5 \text { years }\end{array}$ & $\begin{array}{l}27 \\
\text { infections } \\
\text { during } \\
\text { treatment, } \\
\text { post- } \\
\text { discharge } \\
\text { (flu) }\end{array}$ & $\begin{array}{l}2 \text { patients died } \\
\text { after mobilization } \\
\text { (one from } \\
\text { mucormyosis and } \\
\text { another from } \\
\text { active lupus), } \\
\text { treatment- } \\
\text { related mortality } \\
\text { was } 2 \%(1 / 50)\end{array}$ & 29 & NR & $\begin{array}{l}4 \text { (18 were able to } \\
\text { discontinue } \\
\text { anticoagulation) }\end{array}$ \\
\hline $\begin{array}{l}\text { Hashimoto } \\
(2004) \\
{[35]}\end{array}$ & Improved clinical symptoms of APS & 0 & 0 & 21 & 1 & 0 \\
\hline $\begin{array}{l}\text { Rosen } \\
(2000) \\
{[36]}\end{array}$ & $\begin{array}{l}\text { patients in remission, disease-related } \\
\text { autoantibody titres declined to within the } \\
\text { normal range. Corticosteroid therapy was } \\
\text { gradually reduced in all patients. }\end{array}$ & 0 & 0 & 19 & $\begin{array}{r}\text { all } 3 \text { became } \\
\text { negative }\end{array}$ & 1 \\
\hline $\begin{array}{l}\text { Statkute / } \\
\text { Burt } \\
(2005) \\
{[36]}\end{array}$ & $\begin{array}{l}21 / 28 \text { entered remission of SLE, } 9 / 28 \text { were } \\
\text { able to discontinue all immunosppressive } \\
\text { medications from immediately to } 13 \\
\text { months after transplantation and stayed in } \\
\text { remission from } 12 \text { to } 66 \text { months since } \\
\text { stopping immunosuppression. }\end{array}$ & $\begin{array}{l}9 \text { bacterial } \\
\text { infection, } 2 \\
\text { fungal, } 3 \\
\text { viral }\end{array}$ & 0 & & & 1 \\
\hline $\begin{array}{l}\text { Trysberg } \\
(2000) \\
{[38]}\end{array}$ & $\begin{array}{l}\text { regression of lesions in the brain and spinal } \\
\text { cord }\end{array}$ & 0 & 0 & $\begin{array}{l}18 \\
\text { mont } \\
\text { hs }\end{array}$ & $\begin{array}{l}\text { negative in } \\
\text { first } 6 \\
\text { months }\end{array}$ & 1 \\
\hline $\begin{array}{l}\text { Musso } \\
(1999) \\
{[39]}\end{array}$ & $\begin{array}{l}\text { patient alive and well, with normal blood } \\
\text { counts and persistent low-titre direct anti- } \\
\text { globulin and ANA tests. Anti-dsDNA, LCA } \\
\text { and } \mathrm{aCL} \text { tests are all negative. No further } \\
\text { treatment given. }\end{array}$ & $\begin{array}{l}1 \\
\text { (Pseudomon } \\
\text { as spp.) }\end{array}$ & 0 & 8 & negative & 0 \\
\hline
\end{tabular}

Table 4. Outcomes, mortality and post-transplant clinical characteristics of SAPS patients 


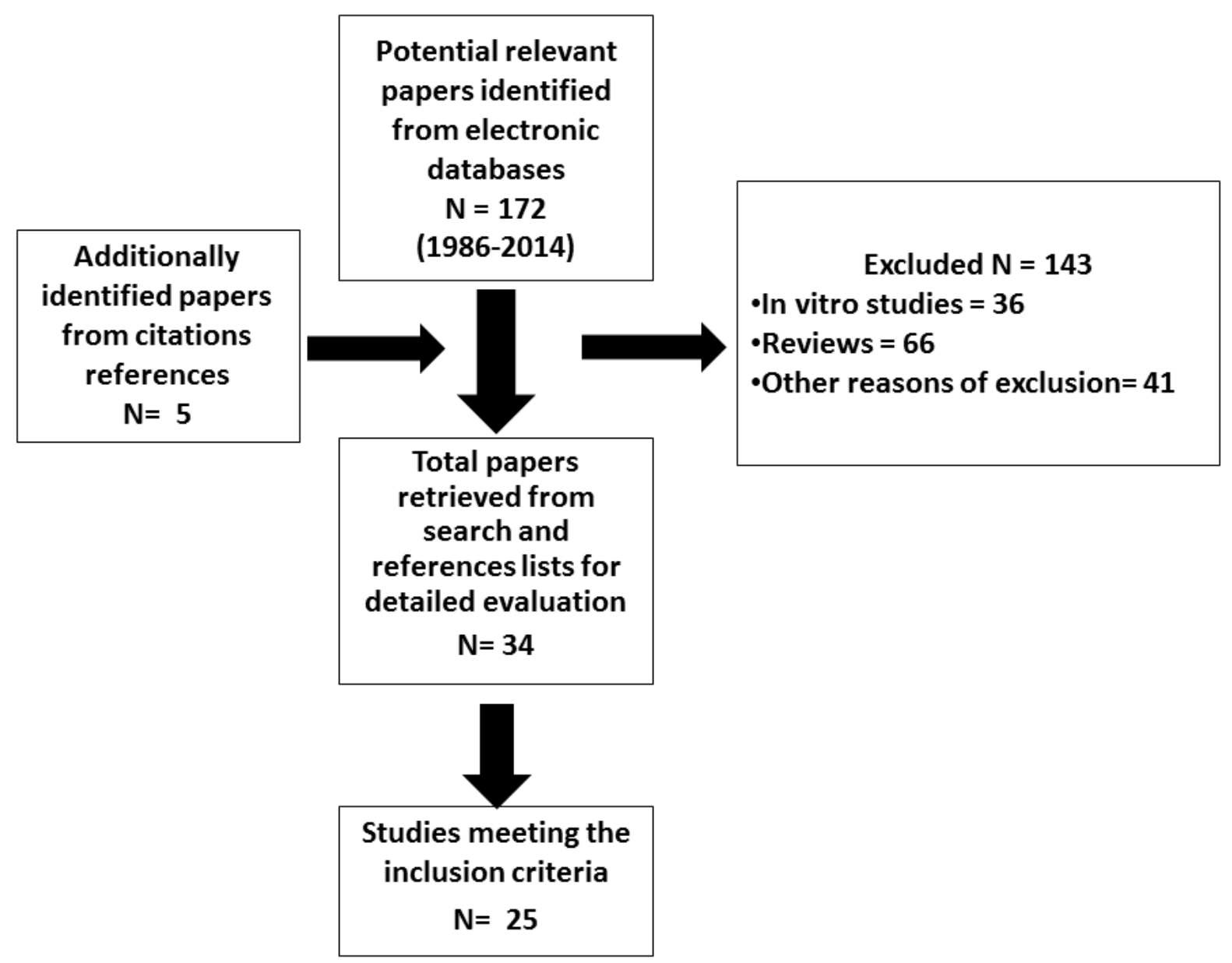

Figure 1. Study selection process 